\title{
6- Göçmen öğrencilerin uzaktan eğitim sürecinde Türkçe derslerinde yaşadıkları sorunlara ilişkin öğretmen görüşleri
}

Faruk KAYMAN'

Veysel ELKATMIŞ2

APA: Kayman, F.; Elkatmış, V. (2021). Göçmen öğrencilerin uzaktan eğitim sürecinde Türkçe derslerinde yaşadıkları sorunlara ilişkin öğretmen görüşleri. RumeliDE Dil ve Edebiyat Araşttrmaları Dergisi, (25), 85-99. DOI: 10.29000/rumelide.1022570.

$\ddot{O} \mathbf{z}$

$\mathrm{Bu}$ çalışmada, göçmen öğrencilerin uzaktan eğitim sürecinde Türkçe derslerinde yaşadıkları sorunların ve bu sorunlara yönelik çözüm önerilerinin Türkçe öğretmenlerinin görüşleri doğrultusunda tespit edilmesi amaçlanmıştır. Çalışmada nitel araştırma yöntemlerinden olan durum çalışmasından yararlanılmıştır. Araştırmanın çalışma grubunu Van ili merkez ilçelerindeki devlet okullarında görev yapan 31 Türkçe öğretmeni oluşturmaktadır. Çalışma grubu amaçlı örnekleme yöntemlerinden ölçüt örnekleme yöntemiyle seçilmiştir. Çalışmada veri toplamak amacıyla yapılandırılmış görüşme formu kullanılmış, elde edilen veriler içerik analizi yöntemiyle çözümlenmiştir. Çalışma sonuçlarına göre göçmen öğrencilerin; Türkçeyi yeterince bilmemek, öğretmen ve öğrencilerle anlaşmakta zorlanmak, sadece derslerde Türkçe konuşma imkânı bulmak, cihaz (tablet, bilgisayar vb.) eksikliği, internetin olmayışı, öğrencinin çalışmak zorunda kalması, kalabalık ev ortamı, evlerin fiziki açıdan yetersiz olması, öğrencilerin hazırbulunuşluk düzeylerinin düşük oluşu, diğer öğrencilerle uyum sorunu yaşamaları, teknolojiyi kullanamamaları, ailelerin ilgisizliği ve eğitime önem vermemeleri, çocuklarını çalıştırmaları, ailelerin eğitim düzeylerinin düşük olması gibi sorunlar yaşadı̆̆ı tespit edilmiştir. Bu sorunlar karşısında Türkçe öğretmenlerinin çeşitli çözüm önerileri sunduğu görülmüş, elde edilen tüm sonuçlar literatürde yer alan çalışmalar ışı̆̆ında tartışılarak yorumlanmıştır.

Anahtar kelimeler: Göçmen öğrenciler, uzaktan eğitim, Türkçe dersi, sorunlar

\section{Teachers' views on the problems immigrant students experience in Turkish lessons during the distance education process}

\begin{abstract}
In this study, it is aimed to determine the problems experienced by immigrant students in Turkish lessons during the distance education process and the solution proposals for these problems in line with the opinions of Turkish teachers. The case study, which is one of the qualitative research methods, was used in the study. The study group of the research consists of 31 Turkish teachers working in public schools in the central districts of Van. The study group was selected by criterion sampling method, one of the purposive sampling methods. In the study, a structured interview form was used to collect data, and the obtained data were analyzed by content analysis method. According to the results of the research, immigrant students; Not knowing Turkish enough, having difficulty in communicating with teachers and students, only having the opportunity to speak Turkish in lessons,
\end{abstract}

Dr., Milli Eğitim Bakanlığı (Van, Türkiye), farukkayman@gmail.com, ORCID ID: oooo-ooo2-7917-7188 [Araştırma makalesi, Makale kayit tarihi: 30.10.2021-kabul tarihi: 20.11.2021; DOI: 10.29000/rumelide.1022570]

Dr., Milli Eğitim Bakanlı̆̆ (Kayseri, Türkiye), veysel.elkatmis@gmail.com, ORCID ID: 00oo-0002-9599-8330

Adres | Address

RumeliDE Dil ve Edebiyat Araştırmaları Dergisi Osmană̆a Mahallesi, Mürver Çiçeği Sokak, No:14/8 Kadıköy - ISTANBUL / TURKIYE 34714 e-posta: editor@rumelide.com

RumeliDE Journal of Language and Literature Studies Osmanağa Mahallesi, Mürver Çiçeği Sokak, No:14/8

Kadıköy - ISTANBUL / TURKEY 34714 tel: +90 $5057958124,+902167730616$

e-mail: editor@rumelide.com

phone: +90 $5057958124,+902167730616$ 
Teachers' views on the problems immigrant students experience in Turkish lessons during the distance education process / F. Kayman; V. Elkatmış (pp. 85-99)

\begin{abstract}
lack of devices (tablets, computers, etc.), lack of internet, having to work for students, crowded home environment, physical inadequacy of houses, low readiness level of students It has been determined that students experience problems such as adaptation problems with other students, inability to use technology, indifference of families and not giving importance to education, having their children work, and low educational level of families. It was seen that Turkish teachers offered various solutions in the face of these problems, and all the results were discussed and interpreted in the light of the studies in the literature.
\end{abstract}

Keywords: Immigrant students, distance education, Turkish lesson, problems

\title{
Giriş
}

Göç olgusu insanlık tarihi kadar eskiye dayanır. İnsanlar savaşlar, iklim şartları, ekonomik nedenler, coğrafi koşullar ve daha birçok sebebe bağlı olarak bir yerden başka bir yere göç etmişlerdir. Bu göçler bazen bireysel bazen de kitleler hâlinde gerçekleşmiştir. Buna bağlı olarak farklı kültürler buluşmuş, toplumlar şekillenmiş, ülkelerin sınırları değişmiş, yeni devletler kurulmuş hatta medeniyetler meydana gelmiştir. Örneğin Avrupa devletlerinin temeli, tarihte bilinen ilk kitlesel göç hareketi olan "Kavimler Göçü” ile atılmıştır (Çapan ve Güvenç, 2017). Yakın tarihe gelindiğinde göç hareketlerinin 2. Dünya Savaşı'ndan sonra yoğunlaştı̆̆ görülmektedir (Karabulut, 2021). Dünya; Pakistan ve Hindistan arasında yapılan nüfus mübadelesi neticesinde 18 milyonluk bir göç hareketi ile en geniş göç dalgasını yaşamıştır (Deniz, 2014). Yine yakın bir tarihte yaşanan Arap Baharı sonrasında çok yoğun göç hareketlerinin gerçekleştiği görülmüştür.

Suriye, adı geçen Arap Baharı hareketinden en çok etkilenen ülke olmuştur. Bu hareketin etkisiyle yaşanan savaş, 5 milyondan fazla insanın ülke içinde yer değiştirmesine ya da komşu ülkelere göç etmesine neden olmuştur. Jeopolitik konumu itibariyle başka ülkelere göç etmek için bir geçiş koridoru veya bizzat göç edilecek bir ülke durumunda olan Türkiye, özellikle Arap Baharı sonrası yoğun göçten en çok etkilenen ülkelerden biri olmuştur. Türkiye, özellikle 2011 yllından bu yana Suriye, Irak, Afganistan, İran, Pakistan ve çeşitli ülkelerden çok sayıda mülteci kabul etmiştir (Akkoyunlu Ertan ve Ertan, 2017). Birleşmiş Milletler Mülteci Örgütünün Şubat-Mart 2021 yllı raporuna göre Türkiye'de 3,6 milyonu Suriyeli olmak üzere Irak, İran, Afganistan, Pakistan ve çeşitli ülkelerden gelenlerle birlikte 4 milyon civarında göçmen bulunmaktadır (BM Mülteci Örgütü, 2021).

Türkiye, yaşanan bu yoğun göçlerden dolayı ekonomik ve toplumsal birçok sorunla karşılaşmaktadır (Akkoyunlu Ertan ve Ertan, 2017). Karşılaşılan bu sorunlara yönelik çalışmalar, AFAD koordinatörlüğünde yürütülmektedir. Örneğin sağllk konusunda Türkiye'de bulunan kayıtlı Suriyelilere AFAD ve Sağlık Bakanlığı işbirliği ile tüm sağlık hizmetleri ücretsiz olarak verilmektedir. Aynı şekilde göçmenlerle ilgili önemli sorunlardan bir diğerinin de eğitim sorunu olduğu görülmektedir. Eğitim sorunu ile ilgili de Türkiye'nin birçok adım attığını söylemek mümkündür. AFAD, YÖK ve Millî Eğitim Bakanlığı işbirliği ile bazı genelgeler yayımlanmış buna göre eğitim sorunlarının çözümüne yönelik çalışmalar gerçekleştirilmiş, öğretmenlere yönelik bazı eğitim çalışmaları yapılmış, çeşitli etkinlikler düzenlenmiş, göçmen çocukların eğitim öğretimlerine bir standart getirilmeye çalışılmıştır. Böylece MEB tarafından göçmen çocukların eğitiminin yasal bir zemine oturtulması hedeflenmiştir (Aksoy, 2020; Şahin, 2020; Seydi, 2014). Türkiye'nin eğitim konusunda göçmenlere sunmuş olduğu hizmetlere bakıldığında Suriyeli öğrencilerin eğitime katılma oranları önemli bir veri olarak kabul edilebilir. Millî Eğitim Bakanlığı Hayat Boyu Öğrenme Genel Müdürlüğünün verilerine göre 2019-2020 eğitim öğretim

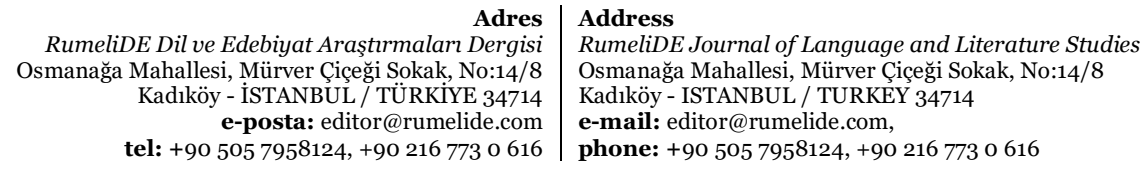


yllında Suriyeli öğrencilerin okullaşma oranı \%63,23 iken bu oran 2020-2021 eğitim öğretim yılında \% 64,22 olarak kaydedilmiştir (Hayat Boyu Öğrenme, 2021).

2019-2020 ile 2020-2021 eğitim öğretim dönemleri aynı zamanda Koronavirüs hastalı̆̆ı olarak bilinen Covid-19 salgınının Türkiye'de etkilerinin görüldügüü dönemdir. Koronavirüs (Covid-19) ilk olarak Aralık 2019 tarihinde Çin'de görülmüş ve Ocak 2020'de tanımlanmıştır (Sağlık Bakanlığı, 2021). Türkiye'de ise 11 Mart 2020'de ilk vaka görülmüş ve hastalığın birkaç ülkede salgına dönüşmesiyle aynı tarihte DSÖ (Dünya Sağllk Örgütü) tarafından pandemi olarak ilan edilmiştir (Serçemeli ve Kurnaz, 2020).

Covid-19 salgını pandemi olarak ilan edildikten kısa bir süre sonra Millî Eğitim Bakanlığı tarafından 16 Mart 2020 tarihinde uzaktan eğitime geçilmesi kararı alınmıştır. Bu doğrultuda Eğitim Bilişim Ağı ve salgın tedbirlerinden dolayı kurulan TRT EBA TV üzerinden eğitim öğretime devam edilmeye başlanmıştır. Bu yolla öğrencilerin eğitim ve öğretimden uzaklaşmalarının önüne geçmek, eğitim hayatlarında olabilecek kayıpları en aza indirmek amaçlanmıştır (Aydın, 2020a). Salgın boyunca okulların kapalı kalması yerine eğitim öğretime uzaktan devam edilmesinin, tüm öğrencilerin yanında zaten dezavantajlı konumda olan mülteciler için de gerekli ve doğru bir yaklaşım olduğu yadsınamaz bir gerçektir. Uzaktan eğitimin faydalı yönleri olmakla birlikte her öğrencinin iletişim ve uygulama araçları konusunda aynı imkâna sahip olmaması gibi bazı sınırlılıkları da bulunmaktadır (Aydın, 2020b). Öğretmen görüşlerine göre Türk öğrenciler için uzaktan öğretim sürecindeki temel problemin teknik anlamda fırsat eşitliğinin olmamasından kaynaklandığı yapılan tespitler arasındadır (Kaplan ve Gülden, 2012). Bunun yanında uzaktan eğitim sürecinin öğrenci, öğretmen ve velileri birçok konuda olumsuz etkilediği görülmüştür (Can, 2020).

Yapılan araştırmalara göre göçmen öğrencilerin normal eğitim öğretim sürecinde birçok konuda sorun yaşadığı tespit edilmiş, bu sorunların genellikle iletişim kuramama sorunu, psikolojik sorun, ekonomik sorun, akademik başarısızlık, akran zorbalığı, öğretmen sorunu, okula kayıt sorunu, materyal sıkıntısı, ötekileştirme gibi sorunlar olduğu görülmüştür (Sarıer, 2020; Cırıt Karaağaç ve Güvenç, 2019; Tanrıkulu, 2017). Bunun yanında göçmen öğrencilerin Türkçe derslerinde en fazla konuşma becerisinde zorlandıkları tespit edilmiştir (Temiz, 2020). Ayrıca Türkçe Dersi Öğretim Programının da göçmen öğrencilere dil becerilerini kazandırma konusunda yetersiz kaldığı, Türkçe ve Türk Dili ve Edebiyatı dersi öğretmenlerinin yabancılara Türkçe öğretimi konusunda yeterli eğitim almadıkları, bu nedenle bu derslerin işlenmesinin zorlaştı̆̆ yapılan çalışmalarla ortaya konmuştur (Koçoğlu ve Yanpar Yelken, 2018; Emin, 2016). Benzer şekilde uzaktan eğitim sürecinde yabancllara Türkçe öğretimi alanında da birçok sorun yaşandığı çeşitli araştırmalarla ortaya konmuştur. 21 üniversitenin Türkçe öğretim merkezinde görev yapan öğretim görevlileri ile yürütülen çalışmada yabancı öğrencilerin en sık, konuşma ve yazma etkinliklerinde zorlandıkları, internet bağlantısı, teknik donanım ve dijital okuryazarlık yetersizliklerinden kaynaklanan sorunlar yaşadıkları tespit edilmiştir (Şengül, 2021). Yine Türkçeyi yabancı dil olarak öğrenen öğrencilerle yapılan bir çalışmada, öğrenciler uzaktan eğitim sürecinde iletişim, etkileşim ve sosyalleşme noktasında zorlandıklarını; derslerin sıkıcı geçmesi, derslere katılımın sağlanamaması, derslere odaklanamama, konuşma kaygısı gibi sorunlar yaşadıklarını; bu nedenle de uzaktan eğitimin konuşma ve yazma becerisini geliştirmediğini, öğretme yönünün zaylf olduğunu, işbirlikli öğrenmeyi engellediğini ifade etmişlerdir (Karatay, Kaya ve Başer, 2021). İlkokula devam eden yabancı uyruklu öğrencilerin uzaktan eğitim sürecinin değerlendirildiği bir diğer çalışmada maddi durum, veli ilgisizliği ve dil sorunu gibi nedenlerle derslere katılımın azaldığı, derslerde verimin düştüğü, sınıf yönetimi ve aktif katılım sağlama konusunda sorunlar yaşandığı görülmüştür (Çalışır ve Özaslan, 2021). İlgili çalışmalar incelendiğinde uzaktan eğitim sürecinde yabancı uyruklu ortaokul öğrencilerinin Türkçe derslerinde karşılaştıkları sorunların ele alındığı

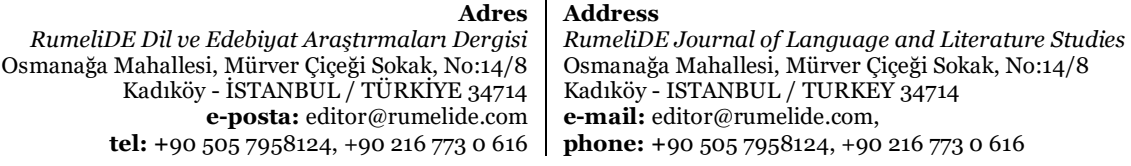


herhangi bir çalışma olmadığı görülmüştür. Buradan hareketle ortaokulda okuyan göçmen öğrencilerin uzaktan eğitim sürecinde Türkçe derslerinde karşılaştıkları sorunların belirlenmesinin gerekli olduğu, bunun için eğitim öğretimin merkezinde yer alan öğretmenlerin konu ile ilgili görüşlerinin bu sorunların giderilebilmesi noktasında önemli olacağı ve alana katkı sağlayacă̆ı düşünülerek böyle bir çalışmanın yapılmasına karar verilmiştir.

\section{Çalışmanın amacı}

$\mathrm{Bu}$ çalışmanın amacı göçmen öğrencilerin uzaktan eğitim sürecinde Türkçe derslerinde yaşadıkları sorunlara ilişkin öğretmen görüşlerini tespit etmektir. Bu amaçla yapılan çalışmada aşağıdaki sorulara yanıt aranmıştır:

- Göçmen öğrencilerin uzaktan eğitim sürecinde Türkçe derslerinde karşılaştıkları sorunlar nelerdir?

- Göçmen öğrencilerin uzaktan eğitim sürecinde Türkçe derslerinde karşılaştıkları sorunlara ilişkin Türkçe öğretmenlerinin çözüm önerileri nelerdir?

\section{Yöntem}

\section{Araştırmanın modeli}

$\mathrm{Bu}$ araştırmada nitel araştırma yöntemlerinden durum çalışması yöntemine başvurulmuştur. $\mathrm{Bu}$ yöntem, çeşitli veri toplama araçları kullanılarak hakkında ayrıntılı bilgi sahibi olunmak istenen durumlar için kullanılır (Creswell, 2015). Bu yöntemin temel amacı, araştırılmak istenen durum veya durumlar hakkında derinlemesine betimlemeler yaparak bunları olduğu gibi anlatmaktır (Büyüköztürk, Kılıç Çakmak, Akgün, Karadeniz ve Demirel, 2018). Nitel araştırmalarda yaygın bir şekilde kullanılan durum çalışmasında elde edilen sonuçlardan hareketle herhangi bir genelleme yapılmaz. Fakat bu sonuçlar, benzer durumların anlaşılabilmesinde bir örnek oluşturması bakımından önemli görülmektedir (Yıldırım ve Şimşek, 2016). Bu çalışmada da Türkçe öğretmenlerinin göçmen öğrencilerin uzaktan eğitim sürecinde karşılaştıkları sorunlar hakkındaki görüssleri incelenerek mevcut durumun betimlenmesi amaçlanmış ve ortaya konan sonuçların bir örnek ve deneyim oluşturacağ düşünülmüştür.

\section{Çalışma grubu}

Araştırmanın çalışma grubunu, Van ili merkez ilçelerine bağlı resmî ortaokullarda görev yapan ve sınıfında göçmen öğrenci bulunan 31 Türkçe öğretmeni oluşturmaktadır. Çalışma grubu amaçlı örnekleme yöntemlerinden ölçüt örnekleme yöntemiyle seçilmiştir. Bu örnekleme yöntemindeki temel düşünce, daha önceden belirlenen birtakım ölçütleri karşılayan durumlara çalışmaktır (Yıldırım ve Şimşek, 2016). Marshall (1996), bu örneklemdeki asıl önemli noktanın, seçilecek durumların bilgi sağlamak bakımından zengin olması olduğunu söyler. Bu çalışmada da Türkçe öğretmenlerinin seçiminde sınıfında en az bir göçmen öğrencinin olması ölçüt olarak belirlenmiş̧ir. Çalışma grubu oluşturulurken öğretmenlerin gönüllü katılımına özen gösterilmiş, bu konuda gönüllü olmayan öğretmenler çalışma grubuna alınmamıştır.

Çalışmaya katılan Türkçe öğretmenlerinin cinsiyet durumları Tablo 1'e aktarılmıştır.

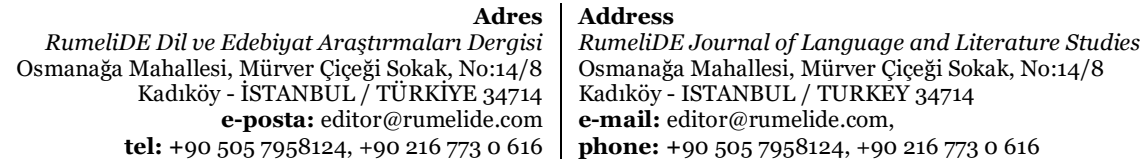


Tablo 1: Katılimclarm Cinsiyet Durumları

\begin{tabular}{lll}
\hline Türkçe Öğretmeni & $\mathbf{f}$ & $\mathbf{\%}$ \\
\hline Kadın & 17 & 61.29 \\
\hline Erkek & 14 & 38.71 \\
\hline Toplam & 31 & 100 \\
\hline
\end{tabular}

Tablo incelendiğinde çalışma grubunda yer alan erkek öğretmen sayısıyla kadın öğretmen sayısının birbirine yakın olduğunu söylemek mümkündür.

Çalışma grubundaki öğretmenlerin görev sürelerine ait bilgiler Tablo 2’ye yansıtılmıştır.

Tablo 2: Katılımcllarn Görev Süreleri

\begin{tabular}{lll}
\hline Görev Süresi & f & \% \\
\hline $1-5$ yll & 9 & 29.0 \\
\hline $6-10$ yll & 9 & 29.0 \\
\hline $11-15$ yll & 7 & 22.6 \\
\hline $16-20$ yll & 4 & 12.9 \\
\hline 21 yll ve üzeri & 2 & 6.5 \\
\hline Toplam & 31 & 100 \\
\hline
\end{tabular}

Tablo 2’ye göre, çalışma grubundaki Türkçe öğretmenlerinin \%29'u (f=9) 1-5 yll arası, \%29’u (f=9) 6-10 yıl arası, \%22,6'sı ( $f=7)$ 11-15 yll arası, \%12,9'u ( $f=4)$ 16-20 yll arası, \%6,5'i $(f=2)$ ise 21 yll ve üzeri meslekî deneyime sahiptir.

Türkçe öğretmenlerinin sınıflarında eğitim gören göçmen öğrencilerin uyrukları Tablo 3’e aktarılmıştır.

Tablo 3: Çalışma Grubundaki Öğretmenlerin Sinıflarında Öğrenim Gören Göçmen Öğrencilerin Uyrukları

\begin{tabular}{lll}
\hline Öğrencinin Uyruğu & f & \% \\
\hline Suriye & 21 & 37 \\
\hline Afganistan & 7 & 26 \\
\hline Irak & 3 & 22.2 \\
\hline Toplam & 31 & 100 \\
\hline
\end{tabular}

Tablo 3'e göre Türkçe öğretmenlerinden 21'inin sınıfında Suriyeli, 7'sinin sınıfında Afgan, 3’ünün sınıfında ise Iraklı öğrenciler öğrenim görmektedir.

\section{Veri toplama aracı}

Göçmen öğrencilerin uzaktan eğitim sürecinde karşılaştıkları sorunları belirlemek ve bu sorunlara yönelik Türkçe öğretmenlerinin sunacakları çözüm önerilerini tespit etmek amacıyla yapılandırılmış görüşme formu hazırlanmıştır. Hazırlanan form Türkçe Eğitimi Bölümünde uzman iki öğretim üyesine gönderilmiş, alınan dönütler sonucunda forma son hâli verilmiştir. Çalışmada kullanılan form iki bölümden oluşmuştur. Birinci bölümde çalışmaya katılan öğretmenin cinsiyeti, mesleki deneyimi ve sınıfında öğrenim gören göçmen öğrencilerin uyruğuyla ilgili üç soru yer almaktadır. Formun ikinci bölümü ise Türkçe öğretmenlerine yönelik iki sorudan oluşmaktadır. Birinci soruda göçmen

RumeliDE Journal of Language and Literature Studies

Osmanağa Mahallesi, Mürver Çiçeği Sokak, No:14/8

tel: +90 $5057958124,+902167730616$

Eadikoy - ISTANBUL / TURKEY 34714

e-mail: editor@rumelide.com

phone: +90 $5057958124,+902167730616$ 
Teachers' views on the problems immigrant students experience in Turkish lessons during the distance education process / F. Kayman; V. Elkatmış (pp. 85-99)

öğrencilerin uzaktan eğitim sürecinde Türkçe derslerinde karşılaştıkları sorunların neler olduğu, ikinci soruda ise Türkçe öğretmenlerinin bu sorunlara karşı ne gibi çözüm önerileri sunabileceği sorulmuştur.

\section{Verilerin toplanması}

Çalışma, 2020-2021 eğitim öğretim yllının ikinci döneminde yapılmıştır. Yapılandırılmış görüşme formu aracılığıyla görüşlerine başvurulacak Türkçe öğretmenlerini tespit etmek amacıyla Van İl Millî Eğitim Müdürlüğünden göçmen öğrencilerin öğrenim gördüğü okulların listesi alınmıştır. Listede yer alan okulların müdürleriyle irtibata geçilmiş, sınıfında göçmen öğrenci olan Türkçe öğretmenlerinin isimleri ve iletişim bilgileri istenmiştir. Daha sonra bu öğretmenlerle görüşülmüş, çalışmaya gönüllü olarak katılmak isteyip istemedikleri sorulmuştur. Çalışmaya katılmak isteyen öğretmenlerle konuşularak belirlenen gün ve saate okullarına gidilmiş ve görüşme formu aracılığıyla görüşleri alınmıştır. Görüşme formları her iki araştırmacı tarafından incelenmiş; eksik, anlaşılmayan veya kapalı kalan bölümler için katılımcı aranarak elde edilen veriler netleştirilmeye çalışılmıştır.

\section{Verilerin analizi}

Çalışmadan elde edilen veriler içerik analizi tekniği kullanılarak çözümlenmiştir. İçerik analizinde amaç, elde edilen verileri okuyucunun anlayabileceği açıklıkta sunabilecek kavramlara ve ilişkilere ulaşmaktır. Bu nedenle ilk etapta veriler kodlanır, bu kodları genel düzeyde açıklayabilecek temalar bulunur, daha sonra veriler bulunan kodlara ve temalara göre düzenlenir ve tanımlanır, nihayetinde ise tanımlanan ve okuyucuya sunulan bulgular araştırmacı tarafından yorumlanır (Yıldırım ve Şimşek, 2016). Bu çalışmada da görüşme formu aracılı̆̆ıyla elde edilen veriler her iki araştırmacı ve Türkçe Eğitimi Bölümünde uzman bir öğretim üyesi tarafından üç defa okunduktan sonra katılımcı görüşleri kodlanmış, benzer kodlar bir araya getirilerek temalar oluşturulmuş, oluşturulan kodlar ve temalar tabloya aktarılmıştır. Tabloya aktarılan bu veriler yorumlanmış ve veriler ışı̆̆ında çeşitli sonuçlar çıarılmıştır. Analiz esnasında katılımcı görüşleri Ö1, Ö2, Ö3... şeklinde kodlanmış, bulguları desteklemek amacıyla her bir tablo altında konuyla ilgili bazı öğretmenlerin görüşleri aynen alıntılanarak verilmiştir.

\section{Geçerlik ve güvenirlik}

Geçerliği ve güvenirliği sağlamak amacıyla çalışmanın başından sonuna kadar titizlikle hareket edilmiştir. Öncelikle çalışmaya katılacak olan öğretmenlerin gönüllü ve istekli olmalarına özen gösterilmiştir. Ayrıca çalışma grubunun konu hakkındaki düşüncelerini tespit etmek için oluşturulan görüşme formu, Türkçe Eğitimi Bölümünde görev yapan iki öğretim üyesinin görüşleri alınarak hazırlanmıştır. Görüşme formu aracıllğıyla elde edilen verilerdeki eksik veya kapalı bölümler, katılımcılarla görüşülerek tamamlanmış veya netleştirilmiştir. Verilerin analizi esnasında sağllklı sonuçlar elde edebilmek için her iki araştırmacıyla birlikte yukarıda bahsi geçen bir uzmanın da katılımıyla veriler kodlanmış, Miles ve Huberman'ın (1994) formülü kullanılarak yapılan hesaplamada kodlamaların güvenirliği 0,82 olarak bulunmuştur. Yine araştırmanın güvenirliğini artırmak için doğrudan alıntılara yer verilmiş, bazı öğretmenlerin ifadeleri olduğu gibi aktarılmıştır.

\section{Bulgular}

Göçmen öğrencilerin uzaktan eğitim sürecinde yaşadıkları sorunları belirlemek ve bu sorunlara karşı önerecekleri çözüm yollarını ortaya koymak için Türkçe öğretmenlerinin görüşlerine başvurulmuş, elde edilen bulgular aşağıda iki başlık hâlinde verilmiştir.

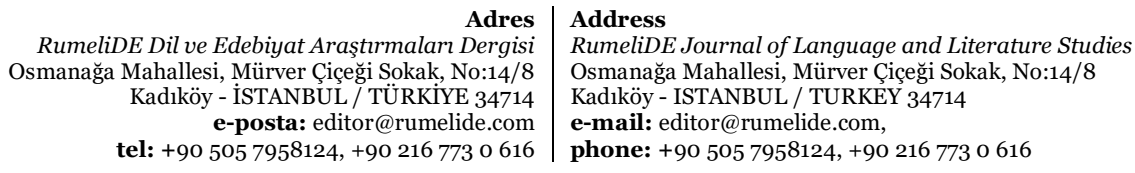




\section{Göçmen öğrencilerin uzaktan eğitim sürecinde Türkçe derslerinde yaşadıkları sorunlar}

Bu başlık altında, göçmen öğrencilerin bu süreçte yaşadıkları sorunlara yer verilmiştir. Çalışma grubunda yer alan Türkçe öğretmenlerinin konu hakkındaki görüşleri analiz edilerek kodlanmış ve bu kodlardan kategoriler oluşturulmuştur. Elde edilen veriler Tablo 4'e aktarılmıştır.

Tablo 4: Göçmen Öğrencilerin Uzaktan Eğitim Sürecinde Türkçe Derslerinde Karşılaştıkları Sorunlar

\begin{tabular}{lll}
\hline Kategoriler & Kodlar & $\boldsymbol{f}$ \\
\hline \multirow{3}{*}{ Dil Sorunu } & Türkçeyi yeterince bilmemek & 26 \\
& Öğretmen ve öğrencilerle anlaşmakta zorlanmak & 18 \\
& Sadece derslerde Türkçe konuşma imkânı bulmak & 10 \\
\hline & Cihaz (tablet, bilgisayar vb.) eksikliği & 25 \\
& İnternetin olmayışı & 21 \\
Ekonomik Sorunlar & Öğrencinin çalışmak zorunda kalması & 14 \\
& Kalabalık ev ortamı & 11 \\
& Evlerin fiziki açıdan yetersiz oluşu & 9 \\
\hline Öğrenciden Kaynaklanan Sorunlar & Hazırbulunuşluk düzeylerinin düşük oluşu & 21 \\
& Diğer öğrencilerle uyum sorunu yaşamaları & 12 \\
& Teknolojiyi kullanamamaları & 11 \\
\hline \multirow{2}{*}{ Veliden Kaynaklanan Sorunlar } & Ailenin ilgisizliği ve eğitime önem vermemesi & 15 \\
& Çocuklarını çalıştırmaları & 9 \\
& Ailenin eğitim düzeyinin düşük oluşu & 7 \\
\hline
\end{tabular}

Tablo incelendiğinde göçmen öğrencilerin uzaktan eğitim sürecinde Türkçe derslerinde karşlaş̧tıkları sorunların dört farklı kategori oluşturduğu görülmüştür. Bunlar; dil sorunu, ekonomik sorunlar, öğrenciden kaynaklanan sorunlar, veliden kaynaklanan sorunlar şeklinde kategorize edilmiştir.

Dil sorunu kategorisinde yer alan sorunlardan birisi bu öğrencilerin Türkçeyi yeterince bilmemeleridir. Bu durumu Ö3, "Türkçeye yeterince hâkim değiller. Eğitim uzaktan olunca bu sorun çok daha büyüyor. Yüz yüze eğitimde bir nebze de olsa aşabiliyorlardı bu durumu fakat canl derslerde Türkçeyi yeterince bilmemeleri çok büyük bir sorun. Bu durum onlart içe kapanmaya da itiyor.” şeklinde ifade etmiştir. Bu kategoride yer alan bir diğer sorun, göçmen öğrencilerin öğretmen ve öğrencilerle anlaşmakta zorlanmalarıdır. Ö14 bu sorunu, "Türkçeyi pek bilmedikleri için ders esnasında hem benimle hem de öğrencilerle anlaşamıyorlar. Bir soru soruyorum fakat yeterince anlamadıkları için birkaç defa tekrarlamak zorunda kahyorum. Bu sorun onları da bizi de çok zorluyor. Bazen kimseyle anlaşamadıkları için çok utanıyorlar. Ayrıca bu öğrencilere canlı derslerde anlatmak daha zor oluyor ve zaman kaybı oluşuyor. Dolayısıyla diğer öğrencilerin de hakkına girmiş oluyoruz.” şeklinde dile getirmiş ve anlaşamama sorununun, beraberinde birçok sorun doğurduğunu ifade etmiştir. Dil sorunu kategorisinde yer alan sorunlardan biri de bu öğrencilerin sadece derslerde konuşma imkânı bulmaları ve bu nedenle de dili bir türlü öğrenememeleridir. Konu hakkında Ö31 şunları ifade etmiştir: "Çocuklarm Türkçeyi sadece derslerde konuşuyor olmasindan mütevellit Türkçe öğrenmekte zorlanması. Bu çocukların Türkçeyi günlük hayatta pek çok platformda konuşabilmeleri gerekir ki bu sorunu aşabilsinler. Canl dersler otuz dakika sürüyor. Derslerde onlara ders mi anlatalım Türkçeyi mi öğretelim?”

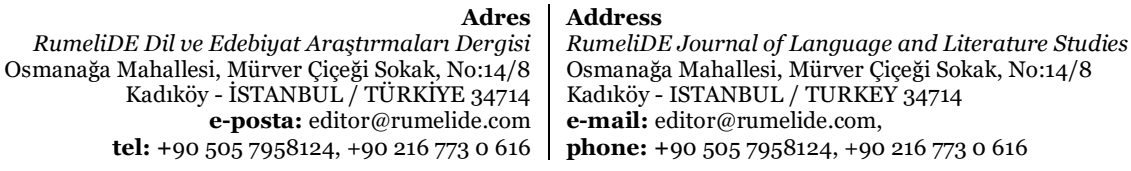


Teachers' views on the problems immigrant students experience in Turkish lessons during the distance education process / F. Kayman; V. Elkatmış (pp. 85-99)

Ekonomik sorunlar kategorisinde beş sorun yer almaktadır. Bunlardan biri cihaz eksikliği sorunudur. Uzaktan eğitimde tablet, bilgisayar vb. teknolojik aletlerin olmayışı öğrencinin hiçbir derse girememesine neden olmaktadır. Diğer öğrenciler gibi göçmen öğrencilerin de bu sorun nedeniyle derslerden uzak kaldığ görülmektedir. Ö22 bu sorunu, "Bilgisayar, tablet vb. materyal eksikliği en büyük sorunlardan biri. Bunlar olmayınca derse giremiyorlar. Bu nedenle yüz yüze eğitimin başlamasın dört gözle bekliyoruz.” şeklinde ifade etmiştir. Cihaz eksikliğinin yanında diğer bir ekonomik sorun bu öğrencilerin evlerinde internet bağlantısının olmamasıdır. Ö2o konu hakkında şunları söylemektedir: "İnternet erişiminin olmaması bu öğrencilerin en büyük handikabı. Yüz yüze eğitimde bu tür sorunlar yoktu fakat uzaktan eğitimde bu eksiklik, yabancı öğrencilerin var olan sorunlarını daha da arttırmıştır." Ekonomik sorunlardan bir diğeri, maddi durumları kötü olduğu için bu öğrencilerin çalışmak zorunda kalmalarıdır. Bu sorunu Ö16, "Çoğunun maddi durumu çok zayıf ve bu süreçte çocuklar babalarıyla çalışmaya gidiyorlar.” şeklinde dile getirmiştir. Diğer bir ekonomik sorun ev ortamının kalabalık oluşudur. Ö13, "Bu öğrencilerin aileleri genelde kalabalık olduğu için ders esnasında çok fazla ses olmakta. Çıkan ses yüzünden çoğunlukla ne dediğimizi anlamıyorlar.” diyerek bu sorunu ifade etmeye çalışmıştır. Evlerin fiziki açıdan yetersiz oluşu da göçmen öğrencilerin karşılaş̧ı̆̆ ekonomik sorunlar arasında yer almaktadır. Ö25’in konu hakkında görüşleri şöyledir: "Ö̆̆rencilerin kendilerine ait bir alanı bulunmadığı için ve yaşadıkları evler az odalı olduğu için tüm ailenin derse katılımı ve gürültü oluşumu.”

Öğrencinin kendisinden kaynaklanan sorunlardan biri bu öğrencilerin hazırbulunuşluk düzeylerinin düşük olması yüzünden dersi anlamakta zorluk çekmeleridir. Ö28 bu sorunu, "Türkçe metinleri okumada sıkınt yaşıyorlar, yazıl anlatım becerileri yeterince gelişmemiş, bir soru sorulduğunda soruya cevap vermekte zorlanıyorlar. Kısacası bu öğrenciler kendi sinıflarındaki öğrencilere göre çok gerideler ve bu durum yüzünden anlattı̆̆ımı çoğu şeyi anlamıyorlar, bir de uzaktan eğitim olunca oldukça zorlanıyorlar.” şeklinde ifade etmiştir. Öğrencilerden kaynaklanan diğer bir sorun, göçmen öğrencilerin diğer öğrencilerle uyum sorunu yaşamalarıdır. Bu durumun canlı derslere de yansıdığını söyleyen öğretmenler, bu sorun yüzünden bazı göçmen öğrencilerin derslere katılmak istemediğini ifade etmişlerdir. Ö11 bu sorunu şöyle açıklamaktadır: “Göçmen öğrencilerin karş̧laştığı en önemli sorunlardan biri de uyum sorunudur. Fakh bir kültürden geldikleri için uyum sağlamakta zorlanıyorlar. Diğer öğrencilerle arkadaşlık kuramıyorlar ya da kurmak istemiyorlar. Derslerde bundan kaynaklanan bir çekingenlikleri var. Uzaktan eğitim aşamasında da aynı sorun var. Bu uyum sorununu atlatamadıkları için bazen derslere bile katılmak istenmediklerini söylüyorlar." Öğrencilerden kaynaklanan sorunlardan biri de teknolojiyi kullanamamalarıdır. Bu durum onların derse katılamamalarına, katılsalar bile verimli ders işleyememelerine neden olabilmektedir. Ö26 bu durumu, "Teknoloji konusunda iyi değiller. Bilgisayar ya da tableti açmakta zorlanan öğrenciler bile var. Eba kullanımını anlamıyorlar (Eba'ya giriş yapamıyorlar).” sözleriyle dile getirmiştir.

Göçmen öğrencilerin Türkçe derslerinde karşılaştıkları sorunların bir kısmı da veliyle, aileyle ilgilidir. $\mathrm{Bu}$ sorunlardan biri velinin derslere, okula karşı ilgisiz olması ve eğitime önem vermemesidir. Ö19 bu sorun hakkında şunları ifade etmiştir: "En büyük sorun ailelerin ilgisizliğidir. Aileler çocuklarıyla yeterince ilgilenmiyorlar. Ĕ̈itime önem vermiyorlar. Canlı derslere katılmayı çok isteyen göçmen öğrencilerim var. Ailesinin durumu kötü değil fakat bu bakış açısı yüzünden çocuk derslere katılamıyor. Çünkü başka işlere gitmek zorunda kalıyor, ev işleriyle uğraşıyor. Aile ilgisiz çünkü. Çocuğun eğitimi onun için çok önemli değil.” Veliden kaynaklanan diğer bir sorun çocukların çalıştırılmasıdır. Dışarıda çalışan çocukların derslere katılamadıklarını söyleyen öğretmenler, evde çalışması gereken başka aile fertlerinin bulunduğunu fakat aileler kendilerince uzaktan eğitimi firsat bilerek çocukları çalıştırdıklarını söylemişlerdir. Ö22 bu sorunu, "Aileler uzaktan eğitimi firsat bilip

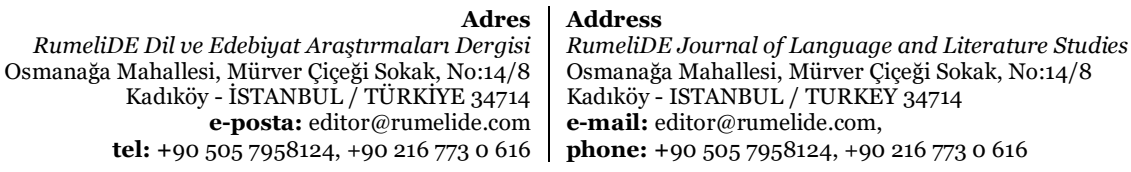


çocukları çalıştırıyor. Evde abileri var çalışmıyor fakat çocuk çahıştırılıyor. Bazı ailelerin buna çok ihtiyacı da yok fakat çocuklar çalıştırıldığı için canlı derslere de katılamıyorlar maalesef." şeklinde dile getirmiştir. Velilerden kaynaklanan sorunlardan biri de eğitim düzeylerinin düşük oluşudur. Bu nedenle öğrenciler öğrenme eylemini yalnız yürütmek zorunda kalmakta, göçmen öğrencilerin daha çok zorlandıkları uzaktan eğitim sürecinde veliler onlara destek olmamaktadır. Ö24 bunu, "Aile eğitim düzeyinin yetersiz olması önemli bir sorun. Öğrenciler dersleri anlamakta zorlanıyorlar, canl derslerde daha çok zorlanıyorlar. Velilerin eğitim düzeyi de düşük olunca öğrenci bu konuda yalnız kalıyor.” sözleriyle ifade etmiştir.

\section{Göçmen öğrencilerin uzaktan eğitim sürecinde Türkçe derslerinde yaşadıkları sorunlara yönelik çözüm önerileri}

Bu bölümde, göçmen öğrencilerin uzaktan eğitim sürecinde Türkçe derslerinde yaşadıkları sorunlara ilişkin Türkçe öğretmenlerinin sunduğu çözüm önerileri yer almaktadır. Sunulan çözüm önerileri aşağıdaki tabloya yansıtılmıştır.

Tablo 5: Göçmen Öğrencilerin Uzaktan Eğitim Sürecinde Yaşadıkları Sorunlara İlișkin Türkçe Öğretmenlerinin Çözüm Önerileri

\begin{tabular}{|c|c|c|}
\hline Kategoriler & Kodlar & $f$ \\
\hline \multirow{3}{*}{ Dil Sorununa İlişkin Çözüm Önerileri } & $\begin{array}{l}\text { Türkçeyi öğrenmelerine yönelik } \\
\text { çalışmalar yapılmalı }\end{array}$ & 23 \\
\hline & $\begin{array}{l}\text { Öğretmenlere yabancılara Türkçe } \\
\text { öğretimi konusunda seminerler } \\
\text { verilmeli }\end{array}$ & 14 \\
\hline & $\begin{array}{l}\text { Aileler bilinçlendirilerek evlerde de } \\
\text { Türkçe konuşulmalı }\end{array}$ & 8 \\
\hline \multirow{4}{*}{ Ekonomik Sorunlara İlişkin Çözüm Önerileri } & Cihaz ve internet desteği verilmeli & 27 \\
\hline & Ailelere maddi destek verilmeli & 18 \\
\hline & Ailelere iş imkânı sağlanmalı & 12 \\
\hline & $\begin{array}{l}\text { EBA destek noktalarının sayısı } \\
\text { arttırılmalı }\end{array}$ & 7 \\
\hline \multirow{4}{*}{ Öğrenciden Kaynaklanan Sorunlara İlişkin Çözüm Önerileri } & $\begin{array}{l}\text { Bu öğrencilere bireysel canlı ders } \\
\text { verilmeli }\end{array}$ & 15 \\
\hline & $\mathrm{Bu}$ öğrencilere uyum eğitimi verilmeli & 15 \\
\hline & $\begin{array}{l}\text { Öğrencilere teknolojik cihazların } \\
\text { kullanımı öğretilmeli }\end{array}$ & 11 \\
\hline & $\begin{array}{l}\text { Öğgrenciler ayrı sınıflarda veya okullarda } \\
\text { eğitim görmeli }\end{array}$ & 7 \\
\hline \multirow{3}{*}{ Veliden Kaynaklanan Sorunlara İlişkin Çözüm Önerileri } & $\begin{array}{l}\text { Ailelere öğrencilerin eğitimine destek } \\
\text { vermeleri için seminerler verilmeli }\end{array}$ & 17 \\
\hline & $\begin{array}{l}\text { Aileler, çocuklarını okula göndermeleri } \\
\text { noktasında teşvik edilmeli }\end{array}$ & 14 \\
\hline & $\begin{array}{l}\text { Ailelerin eğitimine yönelik kurslar } \\
\text { açılmalı }\end{array}$ & 8 \\
\hline
\end{tabular}

Tablo 5’te göçmen öğrencilerin sorunlarına ilişkin Türkçe öğretmenlerinin görüşleri yer almaktadır. Katılımcıların, göçmen öğrencilerin karşılaştıkları sorunlara yönelik 14 farklı çözüm sundukları görülmüştür.

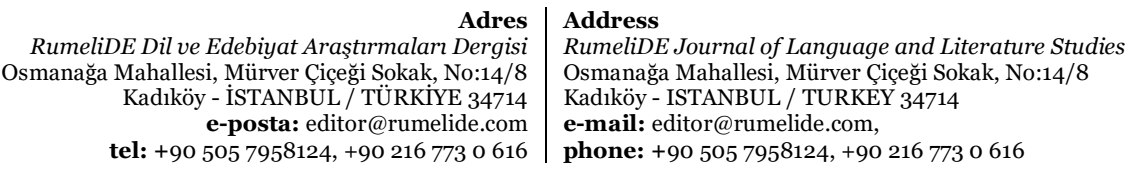


Teachers' views on the problems immigrant students experience in Turkish lessons during the distance education process / F. Kayman; V. Elkatmış (pp. 85-99)

Katılımcılar, dil sorunu kategorisinde yer alan sorunlara yönelik üç farklı çözüm önerisi sunmuşlardır. Türkçeyi yeterince bilmeyen göçmen öğrencilerin bu sorunlarını gidermek için Türkçeyi öğrenmelerine yardımcı olabilecek çalışmaların yapılması gerektiği ifade edilmiştir. Göçmen öğrencilerin öğretmenlerle anlaşmakta zorlandıklarını belirten öğretmenler, öğretmenlerin bu öğrencileri daha iyi anlayabilmeleri ve derslerde daha verimli olabilmeleri için yabancılara Türkçe öğretimi konusunda eğitim almalarının faydalı olacağı dile getirilmiştir. Bu öğrencilerin sadece okulda veya derslerde Türkçe konuştuklarını, bunun dışında Türkçe konuşma imkânı bulamadıklarını söyleyen katılımcılar, öğrencilerin Türkçeyi daha iyi ve daha hızlı öğrenebilmeleri için evlerde de Türkçe konuşmalarının sağlanması gerektiğini ifade etmiş, aileleri konu hakkında bilinçlendirmenin önemini vurgulamışlardır.

Türkçe öğretmenlerinin ekonomik sorunlara ilişkin dört farklı çözüm önerisi sunduğu görülmüştür. Öğrencilerin, cihaz ve internet eksikliği nedeniyle canlı derslere katılamadığını söyleyen öğretmenler, bu sorunu gidermek için Bakanlık tarafından veya hayır kurumları aracılığıyla bu öğrencilere tablet ve internet desteğinin verilmesi gerektiğini vurgulamışlardır. Ayrıca Bakanlığın, evinde internet bağlantısı ve/veya tablet olmayan öğrencilerin canlı derslere katılabilmelerini sağlamak için uygulamaya koyduğu EBA destek noktalarının sayısının artıılması gerektiği söylenmiştir. Öğrencinin çalışmak zorunda kalması nedeniyle canlı derslere katılamaması veya canlı derslere katıldığı hâlde evi küçük olduğu için ve ailedeki fert sayısının fazlalı̆̆ı yüzünden verimli ders işleyemeyişi karşısında iki farklı çözüm önerisi sunulmuştur. Buna göre, öğrencilerin derslere katılabilmesi için veya derslerden istenen verimi alabilmeleri için bu ailelere iş imkânı sağlanmalı veya maddi destek verilmelidir.

Öğretmenler, öğrencinin kendisinden kaynaklanan sorunlara yönelik dört ayrı çözüm önerisi sunmuşlardır. Göçmen öğrencilerin hazırbulunuşluk düzeylerinin düşük olduğunu söyleyen öğretmenler, bu sorunu aşabilmek için bu öğrencilere bireysel canlı ders vermenin daha doğru olacağını dile getirmişlerdir. Bazı katılımcılar ise göçmen öğrencilerin farklı bir sınıfta veya sadece bu öğrencilerin bulunduğu okullarda öğrenim görmelerinin çok daha faydalı olacağını ifade etmişlerdir. Göçmen öğrencilerin uyum sorunu yaşadıklarını, bu nedenle derslerine odaklanamadıklarını vurgulayan katılımcılar, bu sorunu gidermek için bu öğrencilere uyum eğitiminin verilmesi gerektiğini belirtmişlerdir. Teknolojik cihazları kullanma noktasında iyi durumda olmayan öğrencilerin bu sorununu gidermek için ise onlara bu cihazların kullanımına yönelik eğitimin verilmesinin faydalı olacağı söylenmiştir.

Katılımcılar, göçmen öğrencilerin velilerden kaynaklanan sorunlarına ilişkin üç farklı çözüm önerisi sunmuştur. Göçmen ailelerin okula karşı ilgisiz olduklarını ve eğitime önem vermediklerini söyleyen öğretmenler, bu sorunu aşabilmek için ailelere konuyla ilgili farklı seminerlerin verilmesi gerektiğini ifade etmişlerdir. Bazı katılımcılar, göçmen ailelerin ihtiyaçları olmadığı hâlde çocuklarını çalıştırdıklarını dile getirmiş, sorunu giderebilmek için bu ailelerin çeşitli yollarla (eğitici seminerler, ikna) teşvik edilmesi gerektiğini söylemişlerdir. Bazı Türkçe öğretmenleri de ailelerin eğitim düzeylerinin düşük olduğunu vurgulamışlardır. Bu sorunu gidermek ve göçmen ailelerin eğitim düzeyini yükselterek öğrencilere eğitimlerinde yardımcı olmalarını sağlamak için bu ailelerin eğitimine yönelik kurslar açmanın faydalı olacağını dile getirmişlerdir.

\section{Sonuç ve tartışma}

Çeşitli nedenlerle sürekli göç alan Türkiye, özellikle 2011 yllından sonra yoğun bir insan göçüne maruz kalmıştır. BM Mülteci Örgütünün 2021 yılı verilerine göre Türkiye’de bulunan göçmen sayısı, 3,6 milyonu Suriyeli olmak üzere 4 milyonu geçmiştir. 4 milyon göçmenin yaklaşık 1,2 milyonu eğitim 
öğretim çağında bulunmaktadır (Hayat Boyu Öğrenme, 2021). Türkiye yapmış olduğu yasal düzenlemelerle, hangi sebeple olursa olsun ülkede bulunan göçmen çocukları eğitim öğretime dâhil edebilmektedir (Eren, 2019). Göçmenlerin Türk eğitim sistemine entegrasyonu konusunda AFAD, YÖK ve MEB birlikte hareket ederek birçok çalışma gerçekleştirmektedir. Yapılan çalışmalar neticesinde her geçen yıl göçmen öğrencilerin Türk eğitim sistemine daha çok katıldıkları görülmektedir (Hayat Boyu Öğrenme, 2021). Ancak tüm gelişmelere rağmen göçmen öğrencilerin hâlâ müfredat, öğretmen, materyal, dil, koordinasyon, ekonomi ve aile gibi bazı konularda sorunlarla karşılaştıkları belirlenmiştir (Coşkun, vd. 2017; Emin, 2016; Erdoğan, 2014; Özer vd. 2016; Levent ve Çayak, 2017; Seydi, 2014; Yılmaz, 2015; Börü ve Boyacı, 2016; Sarıer, 2020; Crrıt Karaağaç ve Güvenç, 2019; Tanrıkulu, 2017; Temiz, 2020; Koçoğlu ve Yanpar Yelken, 2018; Erdem, 2017,).

Göçmen öğrencilerin uzaktan eğitim sürecinde Türkçe derslerinde yaşadıkları sorunları tespit etmek ve bu sorunlara yönelik çözüm önerilerini belirlemek amacıyla Türkçe öğretmenlerinin görüşlerinin alındığı bu çalışmada farklı sonuçlar elde edilmiştir. Çalışma grubundaki öğretmenlerin görüşleri incelendiğinde uzaktan eğitim sürecinde, Türkçe derslerinde göçmen öğrencilerin karşılaştıkları sorunların çeşitlilik gösterdiği tespit edilmiş̧ir. Bunlar; Türkçeyi yeterince bilmemek, öğretmen ve öğrencilerle anlaşmakta zorlanmak, sadece derslerde Türkçe konuşma imkânı bulmak, cihaz (tablet, bilgisayar vb.) eksikliği, internetin olmayışı, öğrencilerin çalışmak zorunda kalması, kalabalık ev ortamı, evlerin fizikî açıdan yetersiz oluşu, öğrencilerin hazırbulunuşluk düzeylerinin düşük oluşu, teknolojiyi kullanamamaları, diğer öğrencilerle uyum sorunu yaşamaları, ailelerin ilgisizliği ve eğitime önem vermemesi, ailelerin eğitim düzeylerinin düşük oluşu, çocuklarını çalıştırmaları şeklinde ifade edilmiştir. Çalışma grubundaki öğretmenlerin vermiş oldukları cevaplardan hareketle sorunların genel olarak dört farklı kategori oluşturduğu görülmektedir. Bunlar; dil sorunu, ekonomik sorunlar, öğrenciden kaynaklanan sorunlar, veliden kaynaklanan sorunlar şeklinde kategorize edilmiştir.

Çalışmanın bulgularına bakıldığında göçmen öğrencilerin uzaktan eğitim sürecinde, Türkçe derslerinde yaşadıkları sorunların başında dil sorununun yer aldığı görülmektedir. Çalışma grubundaki öğretmenlere göre göçmen öğrencilerin Türkçeyi yeterince bilmemeleri, hem öğretmenle hem diğer öğrencilerle anlaşmakta zorlanmaları ve sadece derslerde Türkçe konuşma imkânı bulmaları bu öğrencilerin en önemli dil sorunları olarak ön plana çıkmaktadır. Temiz (2020), yaptığı çalışmasında normal eğitim döneminde de göçmen öğrencilerin en büyük sorununun dil sorunu olduğunu, bu öğrencilerin Türkçeyi konuşma noktasında zorluk yaşadıklarını belirlemiştir. Aynı şekilde Börü ve Boyacı (2016) da mültecilerin yaşadıkları en önemli sorunu, dil sorunu olarak tespit etmiştir. Erdem (2017), benzer şekilde mülteci öğrencilerin en temel sorununun dil sorunu olduğunu ifade etmiştir. Yine çalışmanın bulgularının yabancılara Türkçe öğretimi alanında yapılan çalışmalarla da örtüştüğü görülmektedir. Zira Şengül (2021), uzaktan eğitim sürecinde Türkçenin yabancı dil olarak öğretiminde öğrencilerin daha çok konuşma ve yazma becerilerine yönelik etkinliklerde zorlandığını ortaya koymuştur.

Çalışma grubunda yer alan Türkçe öğretmenlerine göre mülteci öğrenciler uzaktan eğitim sürecinde dil sorunundan sonra en çok ekonomik nedenlerden kaynaklanan sorunlar yaşamaktadırlar. Özellikle uzaktan eğitimin en önemli ayağı olan internet bağlantısının ve uzaktan erişim sağlayabilecekleri cihazların olmayışı, mülteci öğrencilerin derslere katılamamasına neden olmaktadır. Bunun yanında ailelerin maddi imkânsızlıklardan dolayı çocuklarını çalıştırmak zorunda kalmaları ve elverişsiz ev koşulları nedeniyle öğrencilerin verimli ders işleyememesi gibi nedenlerin, bu öğrencileri uzaktan eğitime katılma konusunda zorladığı yapılan tespitler arasındadır. Ekonomik sebeplerin, göçmen çocukları çocuk işçiliğe, erken yaşta evliliğe zorladığı, bu nedenle eğitimin öncelikli olarak

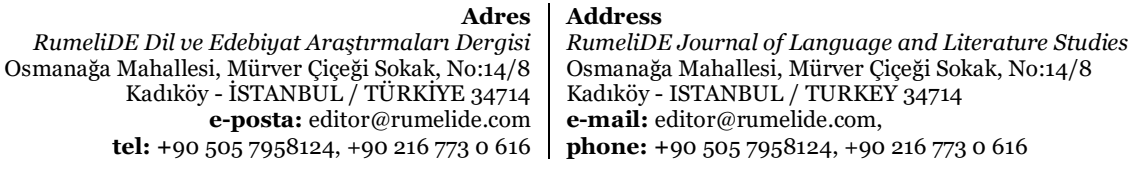


Teachers' views on the problems immigrant students experience in Turkish lessons during the distance education process / F. Kayman; V. Elkatmış (pp. 85-99)

görülmemesine neden olduğu yapılan birçok çalışmada tespit edilmiştir (Uğurlu, 2018; He vd. 2015; Peterson, 2011; UNICEF, 2016). Konuyla ilgili yapılan çalışmalara göre başta Suriyeli öğrenciler olmak üzere mülteci öğrencilerin ekonomik yönden desteklenmesi gerektiği belirtilmiştir (Seydi, 2014; Tanrıkulu, 2017). Karatay, Kaya ve Başer (2021), yaptıkları çalışmada yabancı öğrencilerin uzaktan eğitimi internet, bilgisayar, tablet ve cep telefonu gibi maliyetlerden dolayı ekonomik bulmadıklarını ortaya koymuşlardır. Dolayısıyla bu araştırmanın sonuçlarının yabancılara Türkçe öğretimiyle ilgili yapılmış çalışmaların sonuçlarıyla örtüştüğü söylenebilir.

Çalışma grubu öğretmenlerine göre uzaktan eğitim sürecinde göçmen öğrencilerin yaşadıkları sorunlardan bir diğeri de öğrencinin kendisinden kaynaklanan sorunlardır. Buna göre öğrencilerin teknolojiyi kullanamamaları, diğer öğrencilerle uyum sorunu yaşamaları ve hazırbulunuşluk düzeylerinin düşük olması en temel sorunlardır. Eroğlu ve Okur (2021) tarafından uzaktan eğitimle Türkçenin yabancı dil olarak öğretilmesi sürecinde Türkçeyi öğretmeyi ön hazırlık gerektiren bir süreç olarak değerlendirildiği tespit edilmiştir. Tunga, Engin ve Çă̆ıltay ( 2020) yaptıkları çalışmada öğretmenlerin, göçmen öğrencilerin hazırbulunuşluk düzeylerinin Türkçe derslerine uygun olmadığını, bu nedenle sıkıntılar yaşadıklarını söylediklerini belirtmişlerdir. Emin (2016)'e göre Türkiye'deki göçmenlerin Türkçeyi öğrenememeleri, topluma uyum sağlamalarını geciktirmektedir. Dil sorunu, teknolojiyi kullanamama sorununu da beraberinde getirmektedir. Örneğin göçmen öğrencilerin Eğitim Bilişim Ağından (EBA) yararlanabilmeleri Türkçeyi kullanabilmelerine bağlıdır. Dolayısıyla dil sorunu yaşayan bu öğrenciler, EBA gibi teknolojik çalışmaları takip etmekte zorluk yaşamaktadırlar (Çelik ve Kardaş İşler, 2020). Çalışır ve Özaslan (2021) da yaptıkları çalışmada uzaktan eğitim sürecinde yabancı uyruklu öğrencilerin dil sorunu yaşadıklarını tespit etmişlerdir.

Uzaktan eğitim sürecinde Türkçe derslerinde göçmen öğrencilerin yaşadıkları sorunların bir kısmının da velilerden kaynaklanan sorunlar olduğu yine katılımcılar tarafından ifade edilmiştir. Ailenin ilgisizliği, eğitim düzeylerinin düşük oluşu, ihtiyaç olmadığı hâlde çocuklarını çalıştırmaları, öğrencilerin uzaktan eğitime katılmalarına engel olmaktadır. Erdem (2017)'e göre mülteci ailelerin büyük çoğunluğu ekonomik ve eğitimsel yönden yetersiz durumdadır. Bu durum da çocukların eğitimini olumsuz yönde etkilemektedir. Yine Ergen ve Şahin (2019)'e göre göçmen ailelerin ekonomik ve kültürel sorunları çocukların eğitimine doğrudan yansımaktadır. Aynı şekilde Başar, Akan ve Çiftçi’ye (2018) göre eğitim öğretim sürecinde velilerin yaşadığı dışlanmışlık ve okul-veli iletişimi, velinin öğrenciye desteğini azaltmaktadır. Velinin duyarsızlı̆̆ ve çocuğuna sahip çıkmaması da eğitim öğretimi olumsuz etkileyen bir durumdur (Arabacı vd., 2014). Kaplan ve Gülden (2021) de yaptıkları çalışmada velilerin uzaktan eğitime desteklerinin yetersiz olduğunu tespit etmişlerdir.

Sonuç olarak, bu araştırmadan elde edilen sonuçların hem yabancılara uzaktan Türkçe öğretimi ile ilgili yapılan çalışmaların sonuçlarıyla hem de konuyla ilgili diğer çalışmalarla örtüştügü görülmüştür. Türkçe öğretmenlerinin ifadelerinden hareketle uzaktan eğitim süreci ile normal eğitim sürecinde yaşanan sorunların benzerlik gösterdiğini söylemek mümkündür. Bunun yanında internet bağlantısının olmaması, canlı derslere katılmak için gerekli olan tablet, bilgisayar vb. cihazların bulunmaması, Türkçeyi iyi bilmeyen öğrencilere Türkçe dersinin kazanımlarını canlı dersler vasıtasıyla vermenin zorluğu, ailelerin okulların uzaktan eğitime geçmesini fırsat bilerek çocuklarını çalıştırmaları gibi sorunların uzaktan eğitim süreciyle birlikte ortaya çlkan sorunlar olduğu görülmektedir.

Türk eğitim sisteminde azımsanmayacak bir sayıda olan göçmen öğrencilerin uzaktan eğitim sürecinde yaşadıkları sorunların tespit edilmesi ve bu sorunların çözümü noktasında eğitim öğretimin merkezinde bulunan öğretmenlerden görüş alınması, sorunların çözümüne katkı sağlaması bakımından önemli

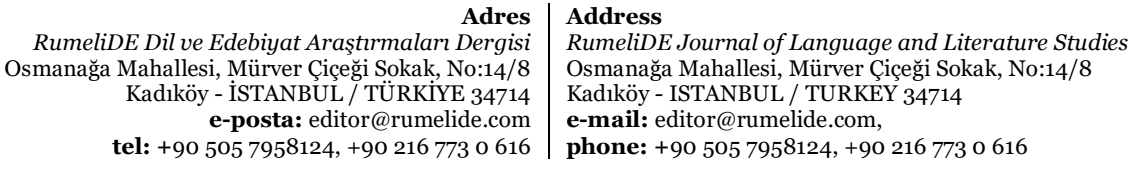


görülmektedir. Bu itibarla çalışma grubunda yer alan Türkçe öğretmenlerinin belirledikleri ve dört kategoriye ayrılan sorunlara karşı yine Türkçe öğretmenlerinin sunmuş oldukları çözüm önerileri şu şekildedir:

- Dil sorununa ilişkin çözüm önerileri: Türkçeyi öğrenmelerine yönelik çalışmalar yapılmalı, öğretmenlere yabancılara Türkçe öğretimi konusunda seminerler verilmeli, aileler bilinçlendirilerek evlerde de Türkçe konuşulmalıdır.

- Ekonomik sorunlara ilişkin çözüm önerileri: Göçmen öğrencilere cihaz ve internet desteği verilmeli, aileler maddi açıdan desteklenmeli, ailelere iş imkânı sağlanmalı, EBA destek noktalarının sayısı artırılmalıdır.

- Öğrenciden kaynaklanan sorunlara ilişkin çözüm önerileri: Bu öğrencilere bireysel canlı ders verilmeli, uyum eğitimi verilmeli, teknolojik cihazların kullanımı öğretilmeli, yine bu öğrenciler ayrı sınıflarda veya okullarda eğitim görmelidir.

- Veliden kaynaklanan sorunlara ilişkin çözüm önerileri: Ailelere öğrencilerin eğitimine destek vermeleri için seminerler verilmeli, çocuklarını okula göndermeleri noktasında aileler teşvik edilmeli, ailelerin eğitimine yönelik kurslar açılmalıdır.

$\mathrm{Bu}$ çalışmada katılımcı öğretmenlerin sunmuş oldukları önerilerin Eroğlu, Topal ve Çalışkan (2021) tarafından yapılan çalışmada Türkçeyi yabancı dil olarak öğretenlerin sunmuş oldukları önerilerle doğrudan ya da dolaylı olarak benzerlik gösterdiği söylenebilir. Zira çalışmada Türkçeyi yabancı dil olarak öğretenlerin Türkçenin yabancı dil olarak uzaktan öğretiminde zengin altyapı ve içerik ihtiyacının karşılanması, konu ile ilgili gerekli eğitimlerin verilmesi ve çevrimiçi derslere uygun platformların oluşturulması gerektiği önerilmektedir.

\section{Kaynakça}

Akkoyunlu Ertan. K. \& Ertan, B. (2017). Türkiye’nin Göç Politikası. İktisat ve Sosyal Bilimlerde Güncel Araşttrmalar, 1(2), 7-39.

Aksoy, E. (2020). Türkiye'deki Suriyeli göçmen çocukların okullaşma durumları. Akademik Hassasiyetler, 7(14), 37-51.

Arabacı, İ.B., Başar, M., Akan, D. \& Göksoy, S. (2014). An analysis about educational problems in camps in which Syrian refugees stay: condition analysis, International Journal of Social Sciences \& Education 4(3), 80-94.

Aydın, E. (2020a). Covid-19 döneminde EBA TV üzerinden yapılan Türkçe derslerinin değerlendirilmesi. Milli Ĕ̆itim Dergisi, 49(1), 877-894.

Aydın, E. (2020b). Covid-19 döneminde EBA ile yapılan uzaktan eğitim sürecinde canlı Türkçe derslerinin değerlendirilmesi. Journal of History School, 50, 512-540.

Başar, M., Akan, D., \& Çiftçi, M. (2018). Mülteci öğrencilerin bulunduğu sinıflarda öğrenme sürecinde karşılaşılan sorunlar. Kastamonu Education Journal, 26(5), 1571-1578.

BM Mülteci Örgütü. (2021, 14 Mayıs). Erişim Adresi: www.unhcr.org/tr/wpcontent/uploads/sites/14/2021/05/UNHCR-Turkey-Operational-Update-February-March2021-TRKF.pdf

Börü, N. \& Boyacı, A. (2016). Göçmen öğrencilerin eğitim-öğretim ortamlarında karşılaştıkları sorunlar: Eskişehir ili örneği, International Periodical for the Languages, Literature and History of Turkish or Turkic 11(14), 123-158.

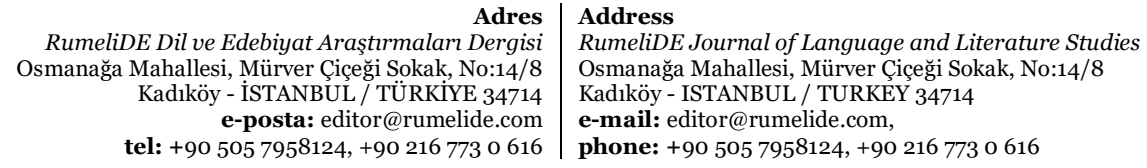


Teachers' views on the problems immigrant students experience in Turkish lessons during the distance education process / F. Kayman; V. Elkatmış (pp. 85-99)

Büyüköztürk, Ş., Kılıç Çakmak, E., Akgün, Ö. E., Karadeniz, Ş. \& Demirel, F. (2018). Bilimsel araşttrma yöntemleri. Ankara: Pegem Akademi.

Can, E. (2020). Coronavirüs (Covid-19) pandemisi ve pedagojik yansımaları: Türkiye'de açık ve uzaktan eğitim uygulamaları. Açıöğretim Uygulamaları ve Araşstrmaları Dergisi, 6(2 ), 11-53.

Cirıt Karaağaç, F. \& Güvenç, H. (2019). Resmi ilkokullara devam eden Suriyeli mülteci öğrencilerin eğitim sorunları. OPUS Uluslararası Toplum Araştırmaları Dergisi, 11(18), 530-568.

Coşkun, İ., Ökten Eren, C., Dama, N., Barkçin, M., Zahed, S., Fouda, M., Toklucu, D., Özsarp, H. (2017). Engelleri Aşmak Türkiye'de Suriyeli Çocukları Okullaştırmak. İstanbul, SETA.

Cresswell, J. W. (2015). Nitel araştırma yöntemleri: Beş yaklaşıma göre nitel araştırma ve araştırma deseni (M. Bütün ve S. B. Demir, çev.). Ankara: Siyasal Kitabevi.

Çalışır, M., Özaslan, H. (2021). Yabancı uyruklu öğrencilerin uzaktan eğitim sürecinin değerlendirilmesi: Bir durum çalışması. RumeliDE Dil ve Edebiyat Araştırmaları Dergisi, (Ö10), 192-213

Çapan, F. \& Güvenç, B. (2017). Kavimler göçü ve Batı Roma İmparatorluğu'nun çöküşü. 21. Yüzyılda Eğitim ve Toplum Eğitim Bilimleri ve Sosyal Araştırmalar Dergisi, 6(18), 629-640.

Çelik, S. \& Kardaş İşler, S. (2020). Göç mağduru Suriyeli öğrencilerin Covid-19 salgını sürecindeki öğrenme deneyimleri. Millî Ĕ̆itim Dergisi, 49 (Özel Sayı 1), 783-800.

Deniz, T. (2014). Uluslararası göç sorunu perspektifinde Türkiye. Türkiye Sosyal Araşttrmalar Dergisi, 181(181), 175-204.

Emin, M. N. (2016). Türkiye'deki Suriyeli çocukların eğitimi: temel eğitim politikaları. Siyaset, Ekonomi ve Toplum Araştırmaları Vakfi Analiz Dergisi, 153, 4-25.

Erdoğan, M. M. (2014). Türkiye'deki Suriyeliler: Toplumsal kabul ve uyum araştırması. İstanbul, İstanbul Bilgi Üniversitesi.

Erdem, C. (2017). Sınıfında mülteci öğrenci bulunan sınıf öğretmenlerinin yaşadıkları öğretimsel sorunlar ve çözüme dair önerileri. Medeniyet Ĕ̆itim Araştırmaları Dergisi, 1(1), $26-42$.

Eren, Z. (2019). Yönetici ve öğretmen görüşlerine göre göçmen çocukların eğitim sorunları ve çözüm önerileri. Bolu Abant İzzet Baysal Üniversitesi Eğitim Fakültesi Dergisi, 19(1), 213-234.

Ergen, H.ve Şahin, E. (2019). Sınıf öğretmenlerinin Suriyeli öğrencilerin eğitimi ile ilgili yaşadıkları problemler. Mustafa Kemal Üniversitesi Sosyal Bilimler Enstitüsü Dergisi, 16(44), 377-405.

Eroğlu, A. \& Okur, A. (2021). Yabancı dil olarak Türkçeyi uzaktan öğretenlerin uzaktan öğretime ilişkin metaforik algıları. RumeliDE Dil ve Edebiyat Araştırmaları Dergisi, (Ö10), 325-338.

Hayat Boyu Öğrenme Genel Müdürlüğü, (2021, 14 Mayıs) Erişim Adresi: https://hbogm.meb.gov.tr/meb_iys_dosyalar/2020_11/18114946_17155955_3_KASIM_202 o__YNTERNET_BULTENY_Sunu.pdf

He, Y., Bettez, S.C. \& Levin, B.B. (2015). Imagined community of education: Voices from refugees and immigrants. Urban Education, 7, 1-29.

Karabulut, A. (2021). Yurt dışına Türk göçü ve göçün etkileri (s. 1-11). İki dilli Türk çocuklarına Türkçe öğretimi içinde (Ed: Karabulut, A. \& Tunagür, M.). Ankara: Akademisyen Kitabevi.

Kaplan, K., Gülden, B. (2021). Öğretmen görüşlerine göre salgın (COVID-19) dönemi uzaktan eğitim ortamında Türkçe eğitimi. RumeliDE Dil ve Edebiyat Araştırmaları Dergisi, (24), 233-258.

Karatay, H., Kaya, S., Başer, D. (2021). Türkçenin yabancı dil olarak öğretiminde uzaktan eğitime yönelik öğrenci görüşleri. RumeliDE Dil ve Edebiyat Araştırmaları Dergisi, (24), 223-232.

Koçoğlu, A. \& Yanpar Yelken, T. (2018). Suriyeli öğrencilere Türkçe dil becerileri kazandırma sürecinde ilkokul Türkçe dersi öğretim programları ile ilgili öğretmen görüşleri. Eğitimde Nitel Araştırmalar Dergisi-Journal of Qualitative Research in Education, 6(2), 131-160.

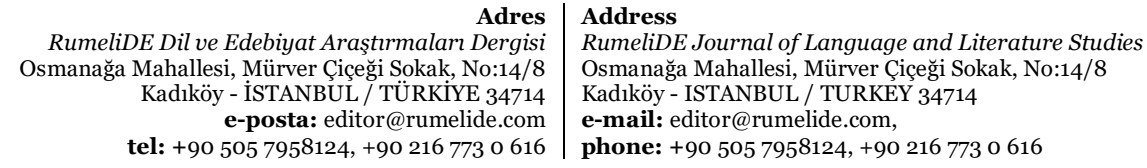


Levent, F. \& Çayak, S. (2017). Türkiye’de Suriyeli öğrencilerin eğitimine yönelik okul yöneticilerinin görüşleri. Hasan Ali Yücel Eğitim Fakültesi Dergisi. 14(27), 17-35.

Marshall, M. N. (1996). Sampling for qualitative research. Family Practice, 13(6), 522-526.

Miles, M. B. \& Huberman A.M. (1994). Qualitative data analysis: An expanded source book. CA: Thousand Oaks, Sage Pub.

Özer, Y.Y., Komşuoğlu, A. \& Ateşok, Z.Ö. (2016). Türkiye'deki Suriyeli çocukların eğitimi: Sorunlar ve çözüm önerileri. Akademik Sosyal Araşttrmalar Dergisi, 4(37), 76-110.

Peterson, S.D. (2011). Conflict, education and displacement. Conflict and Education: An Intedisciplinary Journal, 1(1), 1-5.

Sağlık Bakanlığı, (2021, 14 Mayıs). Erişim Adresi: https://covid19.saglik.gov.tr/TR-66300/covid-19nedir-.html

Sarıer, Y. (2020). Türkiye'de mülteci öğrencilerin eğitimi üzerine bir meta-sentez çalışması: Sorunlar ve çözüm önerileri. Eğitimde Yeni Yaklaşımlar Dergisi, 3(1), 80-111.

Serçemeli, M \& Kurnaz, E. (2020). Covıd-19 pandemi döneminde öğrencilerin uzaktan eğitim ve uzaktan muhasebe eğitimine yönelik bakış açıları üzerine bir araştırma. Uluslararası Sosyal Bilimler Akademik Araştırmalar Dergisi, 4(1), 40-53.

Seydi, A. R. (2014). Türkiye"nin Suriyeli sığınmacıların eğitim sorununun çözümüne yönelik izlediği politikalar. SDÜ Fen Edebiyat Fakültesi Sosyal Bilimler Dergisi, 31, 267-305.

Şahin, H. (2020). Göç olgusu, mülteci çocukların eğitimi ve Suriyeli mülteci çocukların Türk eğitim sistemine entegrasyonu süreci. Uluslararası Türkçe Edebiyat Kültür Eğitim Dergisi, 9(1), 377394.

Şengül, K. (20121). Uzaktan eğitim sürecinde Türkçenin yabancı dil olarak öğretimi. RumeliDE Dil ve Edebiyat Araştırmaları Dergisi, (24), 174-222.

Tanrıkulu, F. (2017). Türkiye'de yaşayan Suriyeli çocukların eğitim sorunu ve çözüm önerileri. Liberal Düşünce Dergisi, 86, 127-144.

Temiz, D. N. (2020). Göçmen ve mülteci öğrencilere Türkçe öğretiminde okulda yapılan oryantasyon çalışmalarının rolü. Uluslararası Liderlik Eğitimi Dergisi, 2(2), 45-59.

Tunga, Y., Engin, G. \& Çağıltay, K. (2020). Türkiye'deki Suriyeli çocukların eğitiminde karşılaşılan sorunlar üzerine bir alanyazın taraması. İnönü Üniversitesi Eğitim Fakültesi Dergisi, 21(1), 317333 .

Uğurlu Eren, Z. (2018). Suriyeli Siğınmacı Öğrencilerin Okula Uyum Sorunlarmın Çözülmesi Ve Desteklenmesinde Öğretmen Etkisi. A. Solak (Ed.) Şiddet ve Sosyal Travmalar içinde (ss. 178242). Ankara, HEGEM.

UNICEF (2016). Türkiye'deki Suriyeli Çocuklar Bilgi Notu Ekim 2016. Erişim Adresi: https://www.unicef.org/turkey/raporlar/t\%C3\%BCrkiyedeki-suriyeli-\%C3\%A7ocuklar-bilginotu-ekim-2016

Yıldırım, A. \& Şimşek, H. (2016). Sosyal bilimlerde nitel araştırma yöntemleri (10. Baskı). Ankara, Seçkin Yayınları.

Yılmaz, A. (2015) Uluslararası göç ve Türkiye'deki çocuk göçmenler ve sığınmacı ailelere tanınan haklar ve daha iyi uygulamalar için öneriler. Akademik Bakış Dergisi, 49, 475-793.

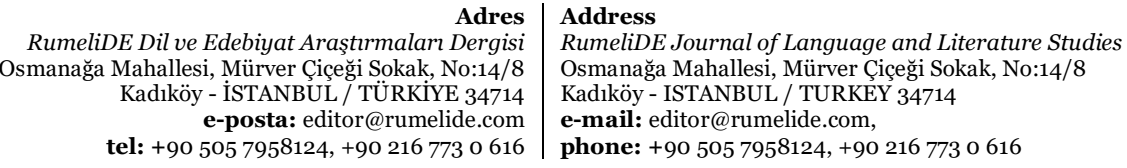

